\title{
DESIGN OF A SURVEY TO EVALUATE PROBLEM-BASED LEARNING METHODOLOGY IN A CORROSION COURSE
}

\author{
R. Sánchez-Tovar, R.M. Fernández-Domene, B. Lucas-Granados, E. Blasco- \\ Tamarit, J. García-Antón \\ Departamento de Ingeniería Química y Nuclear, Universitat Politècnica de València (SPAIN)
}

\begin{abstract}
Problem Based Learning (PBL) methodology was introduced for the first time in a Corrosion course from the Master of Chemical Engineering of the Universitat Politècnia de València, Spain. Different problems involving all these concepts were designed and presented as primary learning methodology over the entire course. This work is focused on the design of a survey for the students in order to: first, know their opinion about the PBL methodology, indicating the advantages and main drawbacks of it and, second, know if this methodology motivates students to seek out a deeper understanding of concepts. This study presents the survey used to evaluate the PBL methodology used during the corrosion course and discuss the obtained results. It is important to point out that this was the first time that students face up to this kind of methodology in university but the general opinion about the methodology is very positive.
\end{abstract}

Keywords: Active methodologies, evaluation, new teaching methodologies, Problem-Based Learning.

\section{INTRODUCTION}

Active teaching / learning methodologies are based on the ideas of current cognitive psychology, in which learning is seen as an active process of construction and reconstruction of knowledge [1, 2]. In this way, it is important to promote the development of skills, abilities and skills essential in the current professional environment from the implementation of active methodologies, and complement that with the acquisition of theoretical concepts.

One of the active teaching / learning methodologies that has been used for a long time is ProblemBased Learning (PBL). It is a methodology in which students are asked to solve, in small groups, problems of different degrees of difficulty and linked to social and professional reality. Once the context of the problem has been introduced, the students should plan, through a cooperative work and under the supervision of the teacher, a solution, identifying their learning needs and management of the problem (promotes the metacognition). In this way, in the PBL, learning is organized from the beginning around the proposed problems, instead of being organized around concepts, principles and theories previously explained to solve problems in class. The classic way of approaching the problemsolving process, at the end of lectures, has little or nothing to do with real life, since problems do not appear that way in the professional world. Therefore, PBL can be considered a concretion of the constructivist orientation of learning, a conexion between the theoretical principles of constructivism and the practice of teaching $[3,4]$. In fact, this methodology has been successfully implemented in several medicine courses, in multiple programs of humanities and social sciences, natural sciences and engineering $[1,5,6,7]$, adapting the problems depending on the areas of knowledge.

In the PBL methodology, the problem is the fundamental factor $[1,3,5,6]$. In order to succeed the problem should generate a cognitive conflict, it should be challenging, interesting and it should motivate students to find the solution. However, problems should not be straightforward because in that case students would become discouraged and this learning methodology will not be useful $[4,5]$.

The PBL evaluation also requires a different approach in comparison to the traditional one, which was based in the memorization of information and facts by students. Evaluation in courses that use the PBL methodology involves the evaluation of a series of specific and transversal competences, challenging the student to reach higher cognitive levels of understanding: apply, analyze, synthesize and create [7]. For this purpose, new evaluation tools should be proposed. Among the different instruments that can be used for this purpose, rubrics are widely used because of their great versatility and didactic potential [7]. The PBL allows generating many activities that can be evaluated: the work of each student, the work of the team as a whole, the presentation (oral and written) of the obtained 
results during the resolution of the problem, and so on. Peer assessment (peer evaluation) and selfassessment (metacognition) [5, 8] can be also used.

Finally, it is important to point out that the educational innovation described in this study implies a significant change that involves completely redefining the objectives of the academic program of the subjects affected, preparing adequate teaching material, designing assessment techniques coherent with the methodologies used and modifying the prevailing mentality of both teachers and students.

\section{METHODOLOGY}

PBL methodology was used for teaching a corrosion course which belongs to the second course of the Master of Chemical Engineering of the Universitat Politècnica de València. Corrosion has 4.5 ECTS and is a very practical course with a great number of problems which covers the following areas:

- Thermodynamics

- Kinetics

- Passivation

- Corrosion cells

- Corrosion protection techniques

- Strategies of design

- Electrochemical techniques to evaluate corrosion

Students also perform laboratory sessions and present an academic work at the end of the course. The academic work is focused on a research study about an industrial corrosion problem.

Since this is the first time that PBL methodology was introduced in this course, a survey was used in order to know the satisfaction of students regarding this methodology. The survey consisted of the following questions. It is important to point out that the two first questions, are general questions related to the course, not only to the PBL methodology. On the other hand, from the third to the eight questions, they are completely related to the PBL methodology.

1 What did you like about the subject? (general question)

2 What would you change of the subject? (general question)

3 Have you ever received any class that was taught using the PBL methodology? (PBL question)

4 Did you like the PBL methodology? (PBL question)

5 Do you see the PBL methodology useful? (PBL question)

6 Has the PBL methodology helped you to better understand the subject? (PBL question)

7 Do you consider that you have learned corrosion with the PBL methodology? (PBL question)

8 Thanks to the PBL methodology, do you consider that in future you will be able to face real corrosion problems? (PBL question)

\section{RESULTS}

The results of the survey are presented below in relation to each of the proposed questions:

According to the first question: What did you like about the subject?, this was a general question about the course, but the purpose of that question was to know if students highlighted the PBL methodology as a positive tool for learning corrosion. Figure 1 shows a summary of the answers to the first question: 


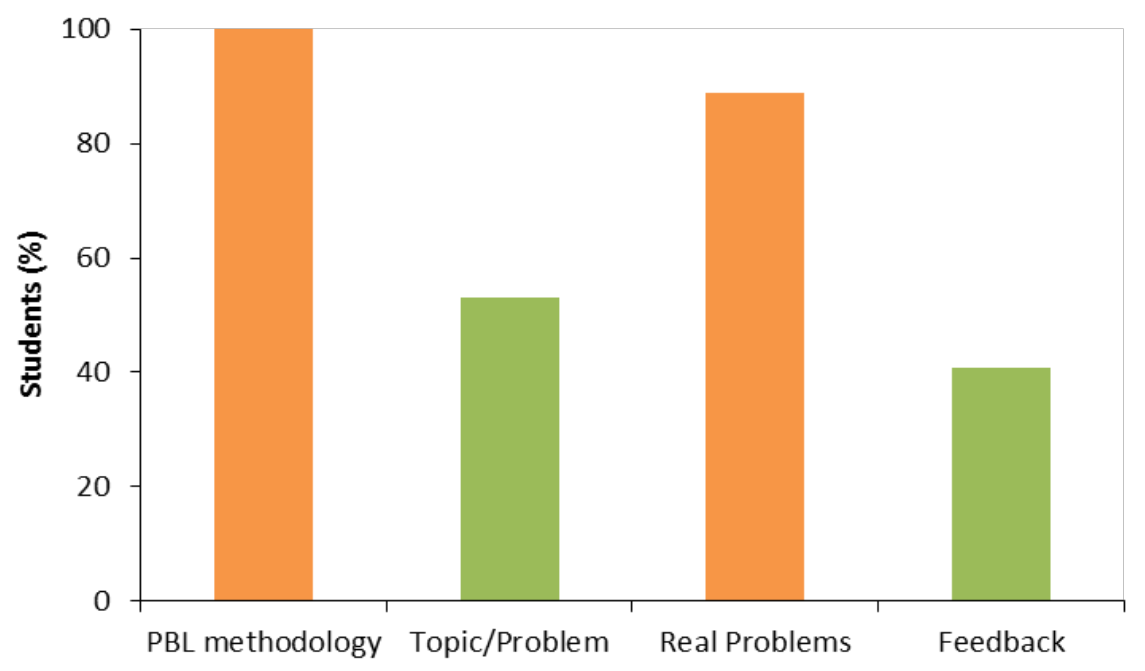

Figure 1. Answers for question 1: What did you like about the subject?

According to Figure 1, all students like PBL methodology and the use of real problems in the teaching methodology. Additionally, most of them consider positive the introduction of one problem per topic and the feedback carried out during the course.

In relation to the second question: What would you change of the subject?, the majority answer nothing, only one of them said that it would be useful to do more laboratory sessions and, in relation to the problems made in class, it would be very positive having a portfolio with the answer of all the problems at the end of the course. According to this suggestion, for the next course, teachers are going to ask students to do a portfolio with the answers of all the PBL problems. The teachers will correct this portfolio during the course in order to increase the feedback with students.

The third question was directly related with the PBL methodology and all agree that this was the first time they were taught with this kind of active methodology.

Regarding the fourth question, all students like the PBL methodology, additionally, they indicated that it was one of the best ways to learn science and engineering subjects. Moreover, they believed that it was easier to learn corrosion with this methodology rather than the traditional one and they assimilated concepts in less time. They also pointed out that this methodology should be introduced in other courses and universities.

In relation to the fifth and the sixth questions (Do you see the ABP methodology useful? and Has the ABP methodology helped you to better understand the subject?), all students answered that this methodology helped them a lot, in particular, they thought that it helps to apply theoretical concepts to real problems.

According to the seventh question: Do you consider that you have learned corrosion with the PBL methodology?, all students answered yes. They also indicated that now, they are prepared to face up to industrial corrosion problems.

In relation to the last question: Thanks to the PBL methodology, do you consider that in the future you will be able to face real corrosion problems? All students answered yes. Moreover, they indicated that their vision to corrosion problems had been changed. Now, they believed that they are more prepared to manage real corrosion problems.

\section{CONCLUSIONS}

In this work a survey in order to evaluate PBL methodology to a corrosion course was carried out. In general, all students like this kind of active teaching methodology and they considered it very useful. In particular, students indicated that with this methodology they are more prepared to face up to and solve real corrosion problems, which are the ones that will appear in their future works.

In relation to one of the answers of the survey, teachers decided to include for the next course a portfolio containing all the PBL problems. This will be done by students and will increase the feedback between students and teachers. 


\section{ACKNOWLEDGEMENTS}

Authors would like to express their gratitude to the project PIME: Aprendizaje Basado en Problemas para su aplicación en las áreas de Ingeniería Química y de Materiales (Ref. 27) and to the Instituto de Ciencias de la Educación and the Vicerrectorado de Estudios, Calidad y Acreditación from the Universitat Politècnica de Valencia, for their financial and technical support.

\section{REFERENCES}

[1] J.C. Perrenet, P.A.J. Bouhuijs, J.G.M.M. Smits, "The Suitability of Problem-based Learning for Engineering Education: theory and practice," Teaching in Higher Education, vol. 5, no. issue 3, pp. 345-358, 2000.

[2] P. Hager, J. Butler, "Two Models of Educational Assessment," Assessment \& Evaluation in Higher Education, vol. 21, pp. 367-378, 1996.

[3] J.A. Llorens-Molina, "El aprendizaje basado en problemas como estrategia para el cambio metodológico en los trabajos de laboratorio" Química Nova, vol. 33, no. Issue 4, pp. 994-999, 2010.

[4] I. Vardi, M. Ciccarelli, "Overcoming problems in problem-based learning: a trial of strategies in an undergraduate unit," Innovations in Education and Teaching International, vol. 45, pp. 345-354, 2008.

[5] J.J. Solaz-Portolés, V. Sanjosé López, A. Gómez López, "Aprendizaje basado en problemas en la Educación Superior: una metodología necesaria en la formación del profesorado," Didáctica de las Ciencias Experimentales y Sociales, vol. 25, pp. 177-186, 2011.

[6] E. López-Zafra, N. Rodríguez-Espartal, L. Contreras, J.M. Augusto Landa, "Evaluación de una experiencia de Aprendizaje Basado en Problemas (ABP) en estudiantes universitarios," Revista d'Innovació Docent Universitària, vol. 7, pp. 71-80, 2015.

[7] A. Fernández March, "La evaluación de los aprendizajes en la universidad: nuevos enfoques", ICE-UPV, 2008.

[8] I. Egido Gálvez, R. Aranda Redruello, R. Cerrillo Martín, A. De la Herrán Gascón, S. De Miguel Badesa, M. Gómez García, R. Hernández Castilla, D. Izuzquiza Gasset, F.J. Murillo Torrecilla, M. Pérez Serrano, R.M. Rodríguez Izquierdo, "El Aprendizaje Basado en Problemas como Innovación Docente en la Universidad: Posibilidades y Limitaciones," Educación y Futuro, vol. 16, pp. 85-100, 2007. 